\title{
Koordinirana obravnava v skupnosti v času epidemije covida-19
}

Sem Katja Čelič, univ. dipl. soc. del., od leta 2006 do avgusta 2021 zaposlena na Centru za socialno delo Novo mesto, z reorganizacijo na CSD Dolenjska in Bela krajina. Delo sem začela na področju socialnih transferjev, izkušnje pa pridobila tudi s področja varstva mladostnikov, varstva otrok in družine, razveze in nasilja v družini ter varstva odraslih. Ob uveljavitvi Zakona o duševnem zdravju (2008) sem se dodatno usposobila in opravila izpit za koordinatorko obravnave $v$ skupnosti in tako na področju duševnega zdravja delam že od novembra 2009. Vsa ta leta sem se tudi dodatno izpopolnjevala (individualno načrtovanje, družinska mediacija idr.).

Obravnava v skupnosti je postopek izvajanja socialnovarstvenih, zdravstvenih in drugih storitev in programov za osebe, ki ne potrebujejo več zdravljenja v psihiatrični bolnišnici ali nadzorovani obravnavi, vendar potrebujejo pomoč pri psihosocialni rehabilitaciji, vsakdanjih opravilih, urejanju življenjskih razmer in vključevanju $\mathrm{v}$ vsakdanje življenje na podlagi načrta obravnave (Zakon o duševnem zdravju, 2008, 91. člen, 1. odst.). Koordinacija obravnave v skupnosti vključuje veliko medinstitucionalnega sodelovanja, zagovorništva uporabnikov, informiranja o pravicah in podporo pri uresničevanju zastavljenih ciljev. Navedeno je bilo v času epidemije covida-19 velik izziv.

V prispevku pišem o svojem delu koordinatorke obravnave $\mathrm{v}$ skupnosti za regijo Dolenjska in Bela krajina v času epidemije covida-19. Na podlagi pogovorov s kolegicami koordinatorkami obravnave v skupnosti ocenjujem, da se vsebinsko reševanje situacije zaprtja služb med regijami po Sloveniji ni občutno razlikovalo.

Leti 2020 in 2021 sta bili tudi na področju duševnega zdravja precej turbulentni. Že v prvem valu epidemije marca 2020 se je pokazala velika stiska ljudi, povezana s covidom-19 in strahovi, kakšne posledice nam bo prinesel ta virus. Takrat osebe, vključene $\mathrm{v}$ obravnavo $\mathrm{v}$ skupnosti, na splošno niso poročale o pretiranih stiskah, saj so ukrepe sprejele kot odgovorno ravnanje pri preprečevanju nalezljive bolezni, so pa nekateri kljub temu potrebovali več telefonskih pogovorov in podpore. Izguba socialnih stikov je na ljudi namreč različno vplivala, še najbolj negativno pa je vplivala na tiste, ki živijo sami in so izgubili stik z dnevnim centrom in drugimi institucijami. V drugem valu epidemije, jeseni 2020, pa sem pri uporabnikih, s katerimi sem sodelovala v okviru koordinirane obravnave v skupnosti, opazila več anksioznosti in daljša depresivna stanja. 


\section{Izzivi uporabnikov}

Ob epidemiji so uporabniki ostali brez dotedanje celostne obravnave v skupnosti. Koordinatorji obravnave v skupnosti smo delali po celotni državi različno, čeprav smo imeli ista navodila Nacionalnega inštituta za javno zdravje, saj smo nekateri morali organizirati delo glede na lastne okoliščine. Nekateri smo zaradi varstva otrok delali v službi izmenično po dnevih. Sama sem imela tudi v času varstva otrok dosegljiv službeni mobitel, na katerega so me lahko klicali tako uporabniki kot sodelavke. Nekateri so delali večinoma od doma, torej je bila koordinatorka obravnave v skupnosti dosegljiva na mobilni telefon in prek elektronske pošte, terenov pa v tem času ni bilo. Nekateri so delali v celoti na delovnem mestu z omejitvami terenskega dela. Navodila so bila, da naj se terensko delo ne opravlja oz. se izvaja samo v nujnih primerih. Sprašujem se, kaj je na področju duševnega zdravja nujno? Po oceni koordinatork obravnave v skupnosti lahko vsak posameznik vsak dan doživlja hude duševne stiske in so osebni pogovori nujno potrebni.

Uporabniki so pogosteje govorili o bolj bolečih temah, o izgubi vpliva na lastno življenje, to so po večini povezovali z osamljenostjo. Zaradi vseh ukrepov je bilo veliko uporabnikov izoliranih od sorodnikov, prijateljev, družabnega življenja, izgubili so dnevno rutino. Zaradi osamljenosti in izgube stikov z zunanjim svetom je bilo izraženih več samomorilnih misli. Različne situacije, npr. izoliranost, slabše materialno stanje, bivanjsko vprašanje, zaposlitev in odnosi, so povečale občutek brezizhodnosti. V zadnjem obdobju covida-19, v primerjavi s prejšnjimi leti, sem pri uporabnikih opazila več krajših hospitalizacij, saj so nekateri nehali jemati predpisano terapijo ali pa so jo prilagodili sami, glede na počutje. Nekateri od njih so sami poiskali pomoč, za druge so poiskali zdravstveno pomoč njihovi sorodniki, za nekatere tudi koordinatorke obravnave v skupnosti. Hospitalizacije so bile v večini primerih krajše, saj so tudi v psihiatrični bolnišnici omejevali sprejeme ali pa so ljudi odpustili, preden so bili zdravstveno stabilni.

Manj je bilo določenih in uresničenih ciljev, zaradi zaprtja podpornih skupin v sklopu nevladnih organizacij in drugih skupinskih aktivnosti. Več je bilo razbremenilnih pogovorov in izpeljanih korakov pri dnevnih opravilih. Nekateri koordinatorji obravnave v skupnosti pa so kljub večjim stiskam uporabnikov na področju duševnega zdravja dobili dodatna druga opravila znotraj nalog centra za socialno delo.

Uporabniki so imeli omejen dostop do pomoči tudi v vseh drugih strokovnih službah. Zaposleni v Skupnostni psihiatrični ambulanti so bili velik del svojih delovnih dni razporejeni na druga delovna mesta (predvsem na odvzem brisov). Do osebnih psihiatrov uporabniki osebno skoraj niso mogli priti, razen pri hudih poslabšanjih zdravstvenega stanja, ko je morala ukrepati urgentna služba. Izjeme so bile pri prejemanju depo terapije (Varnost pacienta pri depo terapiji, 2016). S psihiatri so imeli uporabniki večinoma samo telefonske pogovore. Tudi sami psihiatri so poročali, da prek telefona ne morejo dobro oceniti zdravstvenega stanja oseb in da predpisujejo zdravila glede na vsebino, ki jo povedo pacienti. Zdravstveni sistem se je ustavil tudi na drugih področjih. Nekaterim so večkrat prestavili druge zdravstvene 
preglede in posege. Preostale diagnoze, razen covida-19, so bile pri obravnavi v zdravstvenem sistemu nepomembne, potisnjene v ozadje. To so zelo občutili predvsem uporabniki, ki imajo diagnozi, povezani z duševnim zdravjem, pridružene tudi druge bolezni oziroma hendikep.

Uporabniki so se težje kot v običajnih razmerah srečali tudi s strokovnimi delavkami centra za socialno delo. Vloge za uveljavljanje pravic iz javnih sredstev so pošiljali po pošti ali oddajali v nabiralnik na posameznih enotah. Ni bilo več osebnih pogovorov z osebami, ki so v preteklosti lahko ujele tudi kakšne druge stiske oseb, zaradi katerih so potem usmerile posameznike $\mathrm{v}$ dodatne storitve znotraj centra za socialno delo ali na druge organizacije.

Tudi dnevni centri so zaprli vrata skupinskim srečanjem in so bili prisiljeni preoblikovati svoje storitve. Uporabniki so tako izgubili dnevno rutino, s strokovno službo so obdržali samo telefonske stike oz. individualne pogovore po predhodnem dogovoru. Z vidika upoštevanja navodil Nacionalnega inštituta za javno zdravje je bilo to sicer razumljivo, z vidika socialne vključenosti pa je bilo ljudem težko sprejeti vse te omejitve. Sploh tistim, ki so leta vsak dan hodili v dnevni center in se družili ter razvijali svoje socialne spretnosti.

Pri uporabnikih sem opazila posledice ukrepov za zajezitev covida-19 in z njimi povezanim zaprtjem strokovnih služb, in sicer v obliki večjih osebnih stisk. Potrebnega bo več časa za vnovično zaupanje zdravstvenemu sistemu in sistemu socialne varnosti, da se bodo počutili slišane v svoji stiski in da bodo dobili vso zdravstveno pomoč, ki jo potrebujejo.

Nekateri uporabniki so šli v službi na čakanje. Znižali so se jim mesečni prihodki. Veliko izzivov so imeli starši s poučevanjem otrok. Dlje je trajalo, da so jih obravnavali na Zavodu RS za zaposlovanje in Zavodu za pokojninsko in invalidsko zavarovanje. Dlje je trajal postopek pridobitve pravice do osebne asistence, do programa socialne vključenosti, nekateri so službo izgubili. Bil je tudi primer, ko je bila oseba že konec leta 2020 izbrana na delovno mesto, pa ni mogla delati zaradi zaprtja podjetja oz. dela od doma in ji je potekel zdravniški pregled za začetek delovnega razmerja, to pa je bil potem na začetku 2021 razlog, da osebe niso zaposlili.

Sem pa pri uporabnikih zaradi epidemije ugotovila tudi nekaj pozitivnih premikov v načinu razmišljanja in delovanja. Večina uporabnikov se je namreč ozrla vase in se želela pogovarjati o smislu življenja, svojih osebnejših ciljih, svojih občutjih, smislu vsega, kar delajo. Večina uporabnikov je potrebovala in tudi dobila več telefonskih razbremenilnih pogovorov. Nekateri so se bolj povezali z lokalno skupnostjo: sosedi, sostanovalci, sorodniki. Naučili so se novih spretnosti uporabe socialnih omrežij in aplikacij Zoom, Skype ipd. Veliko uporabnikov je več bralo knjige in nekateri so se poglobili v pisanje dnevnika, knjige ali drugo ustvarjanje, oživili so igranje instrumenta in podobno.

\section{Izzivi in priložnosti za strokovno delo}

Veliko strokovnih delavk nas je plulo med službenimi obveznostmi in domačimi dolžnostmi, prav tako smo prilagajale delo z uporabniki in reševale nujne stiske, kljub omejitvam. Terenskega dela je bilo manj, ob obiskih pa smo se zadrževali 
večinoma na terasah ali pa smo se manj časa zadrževali v zaprtih prostorih in imeli odprta okna. Tudi strokovne službe smo se v zadnjem času bolj povezale. V času covida-19 je postala medsebojna odvisnost še očitnejša, zato smo začeli tesneje sodelovati za blaginjo uporabnikov. Tako sem v času epidemije covida-19 večkrat prejela klic psihiatra, osebnega zdravnika in socialne službe psihiatrične bolnišnice kot klic na pomoč in podporo za njihovega pacienta. Vedeli so, da smo koordinatorji obravnave v skupnosti bližje uporabnikom in zato lažje pridemo do osebnega stika z uporabniki. Takoj smo poiskali nove možnosti za srečanja z uporabniki, izkoristili sodobno tehnologijo, socialna omrežja in se z uporabniki srečevali zunaj. Iskali smo možnosti za vnovična srečanja v živo in takoj, ko je bilo možno, smo se začeli srečevati skupinsko.

V času epidemije sem uporabila več razbremenilnih pogovorov prek telefona, nekaj prek Zooma, prek elektronskih sporočil, več je bilo telefonskih sporočil. Multidisciplinarne time sem v času zaprtja opravljala prek telefona ali v obliki korespondenčne seje, ko pa je le bilo možno združevanje do nekaj oseb, pa vedno osebno. $\mathrm{V}$ zadnjem obdobju je bilo manj zapisanih načrtov obravnave $\mathrm{v}$ skupnosti, smo pa veliko korakov dosegali že med samo obravnavo oz. med pogovori. Kar nekaj ciljev je bilo neuresničenih zaradi zaprtja države in neizvajanja storitev. Vsi cilji, povezani z zaposlitvijo ali socialno vključenostjo, so mirovali več kot pol leta. $V$ tem času pa se je pri nekaterih zdravstveno stanje že toliko poslabšalo, da smo spet začeli na novo, s hospitalizacijo in novo zastavljenimi koraki. Imela sem več primerov brezupa in groženj s samomorom. Na to sem se odzvala s klicem na nujno medicinsko pomoč in dvakrat tudi na policijo, da so osebo najprej izsledili. Na srečo so imele vse zgodbe srečen konec. Hvaležna sem, da so zdravstvene službe v nujnih primerih delovale brezhibno.

\section{Odzivanje na potrebe uporabnikov}

Vključeni uporabniki so mi sporočali, da si želijo biti vsaj nekomu pomembni, vsaj pri nekomu slišani, vsaj nekje koristni in vključeni vsaj v kakšno skupino. Ko sem slišala njihove besede, je nastala prva podporna skupina v sklopu obravnave v skupnosti.

Skupino za samopomoč sem izvajala po programu Dobro sem - krepitev duševnega zdravja ranljivih skupin ${ }^{1}$. Izvajati smo ga začeli junija 2021. V skupino sem povabila osebe, ki so bile vključene v obravnavo v skupnosti na CSD Dolenjska in Bela krajina, so zdravstveno stabilne in so v času covida-19 izražale občutke osamljenosti in željo po novih poznanstvih in podpori v skupnosti. Za srečanja se je odločilo 6 oseb, 5 žensk in 1 moški, v starosti od 21 do 59 let. Od junija do avgusta 2021 smo na 12 srečanjih skupaj z uporabniki obravnavali zanimive teoretske vsebine in izvedli veliko vaj za osebnostni razvoj. Teme de-

1 Program Dobro sem (2021) so pri Zvezi prijateljev mladine Ljubljana Moste-Polje zasnovali leta 2015. Namenjen je ozaveščanju in izobraževanju posameznikov iz ranljivih skupin, $s$ ciljem, da lažje vplivajo na svoje duševno zdravje in dobro počutje, ga krepijo in varujejo. V programu razvijajo in implementirajo celovite preventivne vsebine psihosocialne pomoči in izobražujejo trenerje prostovoljce, ki v lokalnih okoljih izvajamo podporne skupine. Program Dobro sem je za vse udeležence brezplačen. 
lavnic so bile: spoznavanje sebe, samopodoba, temeljna prepričanja in vzorci, izražanje čustev, načini komuniciranja in načini izražanja sebe, konflikti in načini reševanja problemov oz. izzivov, odnosi in načini izražanja ljubezni, stres in izgorelost, sproščanje in čuječnost, določanje ciljev idr. Večino srečanj smo izvedli v mirnem parku, sedeli smo na travi na blazinah, na primerni razdalji brez mask. To nam je omogočalo osebno povezanost. Skupina se je že na začetku zelo dobro povezala in prav vsi so poročali, da jim je bilo v zadnjem letu najtežje to, da niso imeli podporne socialne mreže in predvsem stikov s podobno mislečimi. Člani skupine so si pred koncem srečanj izmenjali telefonske številke in si oblikovali skupino na socialnem omrežju. Tam se redno slišijo in tudi osebno dobivajo. Izrazili so željo, da se skupinska srečanja nadaljujejo tudi v jesenskem delu skupaj s koordinatorji obravnave v skupnosti in z možnostjo sprejema novih članov.

O izkušnji podporne skupine so povedali, da so bili v družbi z dobrimi ljudmi in da so bili sprejeti natanko takšni, kot so. Stkali so nova prijateljstva in pridobili novo podporo $\mathrm{v}$ skupnosti.

Prav iskanje novih načinov, kako ohraniti uporabnike vključene v skupnosti (ne glede na razmere) tako, da lahko izrazijo sebe, je bistvo strokovnega dela v socialnem delu.

\section{Kaj smo se naučili?}

Zadnje obdobje, ko so nas zaznamovali covid-19 in z njim povezane omejitve, je v nas zbudilo veliko novih občutkov. Ustavilo nas je, da smo se obrnili vase, tako uporabniki kot strokovne delavke, in izluščili, kaj je za nas nujno potrebno za preživetje, in ugotovili, da ne glede na vse med nujne potrebe vsakega človeka sodita tudi socialna vključenost in osebna podpora sočloveka.

Koordinatorji obravnave v skupnosti smo se v tej zmedi znašli vsak po svoje in iskali načine, kako biti še vedno blizu ljudem. Tudi mi smo se med epidemijo srečali vsaj vsak mesec $v$ obliki supervizije in ohranjali stike tudi s telefonskimi pogovori. Tako smo si lahko izmenjali izkušnje in se podprli tudi v za nas zahtevnih okoliščinah dela. Tudi za strokovne delavke je pomembno, da najprej poskrbijo zase, da lahko srčno podpirajo uporabnike v njihovih velikokrat hudih preizkušnjah. Verjamem, da smo zdaj že bolje pripravljeni na nove preizkušnje in tudi na nove načine stika z uporabniki. Želimo pa si, da bi se okoliščine dela čim prej stabilizirale, da bomo lahko ohranjali pristne osebne stike z uporabniki. Kot je bil tudi cilj reorganizacije centrov za socialno delo - "Na teren, bližje k ljudem". Naj se zgodi in obstane.

$V$ zadnjem več kot enem letu koordinirane obravnave sem spoznala, da bomo samo skupaj premagovali podobne prihodnje preizkušnje. In prav gotovo sem še bolj ugotovila, da je edina stalnica sprememba, na katero se moram iz dneva v dan prilagajati in ohraniti zaupanje, da bo vse v redu. Predvsem pa vsi potrebujemo osebni stik. Ta mora biti omogočen ne glede na vse omejitve in pogoje za vključitev. 


\section{Viri}

Dobro sem (2021). Pridobljeno 6. 11. $2021 \mathrm{~s} \mathrm{https://www.zpmmoste.net/dobro-sem}$

Varnost pacienta pri depo terapiji (2016). Pridobljeno 6. 11. $2021 \mathrm{~s} \mathrm{https://www.zdravstve-}$ na.info/vsznj/varnost-pacienta-pri-depo-terapiji-psihiatrija-depo-terapija-depo/

Zakon o duševnem zdravju (2008). Ur. l. RS, št. 77/2008. 